\title{
SISTEM PENDUKUNG KEPUTUSAN PENJURUSAN PADA SISWA SMA
}

\author{
Susi Susanti ${ }^{1}$, Dyah Ayu Irawati ${ }^{2}$, Ridwan Rismanto ${ }^{3}$ \\ Program Studi Teknik Informatika, Teknologi Informasi, Politeknik Negeri Malang \\ susi_329@yahoo.com,dyah.ayu.irawati@gmail.com, ridwan@polinema.ac.id
}

\begin{abstract}
Abstrak
Penjurusan pada siswa SMA dilakukan ketika siswa berada dikelas X. Jurusan yang ada di SMA Negeri 1 Tumpang antara lain IPA, IPS dan Bahasa. Penjurusan berdasarkan kemampuan dan minat siswa. Penjurusan di SMA Negeri 1 Tumpang memiliki beberapa kriteria yaitu, nilai rapor, nilai UN, psikotes, angket dan wawancara. Keakuratan dalam perhitungan kriteria penjurusan sangat penting agar proses penjurusan sesuai dengan target. Dalam proses penjurusan guru BK mengalami beberapa kendala dalam mengkalkulasikan kriteriakriteria tersebut karena guru BK masih menggunakan bantuan Microsoft Excel dalam mengkalkulasi semua kriteria, sehingga dibutuhkan waktu yang lama dan ketelitian dalam proses perhitungannya.

Pada Penelitian ini dibuat sebuah Sistem Pendukung Keputusan untuk membantu guru BK dalam menentukan penjurusan dengan mengimplementasikan metode SAW (Simple Additive Weighting) dalam pengembangannya. Sistem ini menggunakan metode SAW karena dalam metode ini dapat menentukan nilai bobot untuk setiap atribut, kemudian dilanjutkan dengan proses perangkingan yang akan menyeleksi alternative terbaik dari sejumlah alternative. Dengan metode perangkingan tersebut, diharapkan penilaian akan lebih tepat karena didasarkan pada nilai kriteria dan bobot yang sudah ditentukan sehingga akan mendapatkan hasil yang lebih akurat terhadap penilaian penjurusan tersebut.

Pengujian yang dilakukan pada penelitian ini membandingkan hasil dari Sistem Pendukung Keputusan dengan hasil manual selama 2 periode tahun ajaran. Berdasarkan hasil pengujian tersebut, Sistem Pendukung Keputusan memiliki keakurasian $71.0462 \%$ pada tahun 2015 dan $71.6088 \%$ pada tahun 2014
\end{abstract}

Kata Kunci: SPK, Penjurusan, SAW

\section{Pendahuluan}

\subsection{Latarbelakang}

Program penjurusan pada Sekolah Menengah Atas dilakukan ketika siswa berada dikelas X. Jurusan yang tersedia di SMA meliputi Ilmu Pengetahuan Alam (IPA), Ilmu Pengetahuan Sosial (IPS), dan Ilmu Bahasa (Bahasa).

Selama ini guru BK SMAN 1 Tumpang berperan penuh dalam menentukan penjurusan pada siswa baru, dimana guru BK mengkalkulasikan seluruh kriteria penilaian seperti: nilai rapor, nilai rata-rata SKHU, nilai psikologi dan angket siswa. Selain mengkalkulasikan keempat kriteria tersebut, guru BK juga menilai kemampuan dan minat bakat dari siswa dengan melakukan sesi wawancara terhadap siswa, kemudian hasil wawancara akan disesuaikan dengan hasil kalkulasi kriteria sehingga akan dihasilkan jurusan yang dianggap sesuai dengan siswa tersebut. Namun dalam mengkalkulasikan keempat kriteria tersebut guru BK memerlukan banyak waktu sehingga hal ini dapat memperlambat proses penjurusan, sehingga akan dibangunlah sebuah Sistem Informasi Penentuan Jurusan pada siswa sma di SMA Negeri
1 Tumpang, yang dapat membantu guru BK dalam menentukan penjurusan bagi siswa baru ini menggunakan metode SAW (Simple Additive Weighting)).

Dalam pengembangan sistem ini menggunakan metode SAW karena dalam metode ini menentukan nilai bobot untuk setiap atribut, kemudian dilanjutkan dengan proses perangkingan yang kan menyeleksi alternative terbaik dari sejumlah alternative, yang dimaksud adalah berdasarkan kriteria-kriteria yang ditentukan. Dengan metode perangkingan tersebut, diharapkan penilaian akan lebih tepat karena didasarkan pada nilai kriteria dan bobot yang sudah ditentukan sehingga akan mendapatkan hasil yang lebih akurat terhadap penilaian penjurusan tersebut.

\subsection{Rumusan Masalah}

Berdasarkan latar belakang diatas, maka rumusan masalah adalah sebagai berikut:

1. Bagaimana membuat aplikasi yang dapat membantu proses peminatan pada siswa sma kelas x di SMA Negeri 1 Tumpang. 
2. Bagaimana merancang sistem pendukung keputusan dengan metode (SAW) Simple Additive Weighting .

3. Bagaimana sistem ini dapat membantu guru BK dalam menentukan penjuruan bagi siswa baru di SMAN 1 Tumpang?

\subsection{Tujuan} dicapai :

Adapun tujuan dari penelitian ini yang dapat

1. Merancang dan membangun Sistem Informasi Penentuan Jurusan dengan menggunakan metode (SAW) Simple Additive Wighting dan metodologi (RAD) Rapid Application Development.

2. Sistem informasi ini dapat membantu guru BK dalam menentukan jurusan pada siswa baru SMA Negeri 1 Tumpang.

\section{Landasan Teori}

\subsection{Penelitian terdahulu}

Penelitian di bidang sistem pendukung keputusan menggunakan metode SAW telah banyak dilakukan dan terus mengalami perkembangan. Beberapa penelitian menggunakan fuzzy dan SAW sebagai metode dalam sistem pendukung keputusan diantaranya dilakukan oleh Herry Wibowo dan Riska Amalia, dkk (2009) . Herry Wibowo dan Riska Amalia menggunakan metode SAW untuk menentukan penerima beasisswa bank bri dari penelitian ini didapat kesimpulan bahwa semakin banyak data yang dipunyai, maka tingkat validasinya akan cenderung naik. Sama halnya dengan penelitian yang dialkukan oleh Herry wibowo dan Riska Amalia, Dwi Citra dan Endang dkk juga menggunakan fuzzy dan SAW dalam penelitianya yang mendukung keputusan dalam pemilihan hotel di kota Palembang. Dalam penelitian ini Dwi Citra dan Endang dkk, menggunakan fuzzy untuk merubah bobot menjadi bilangan fuzz. Kriteria yang dibutuhkan untuk menetukan hotel yang terpilih sebagai hotel yang terbaik adalah harga sewa kamar, lokasi, dan fasilitas kelas.

\subsection{Sistem Pendukung Keputusan}

Sistem pendukung keputusan (Descision Support System -DSS) adalah bagian dari computer based information system (CBIS). Secara umum CBIS meliputi berbagai macam sistem informasi, seperti sistem pemrosesan transaksi (Transaction Processing System - TSP), sistem iinformasi management (Management Information System MIS), sistem pendukung manajemen ( Management Support System) dan Sistem otomatisasi perkantoran ( Office Automation System). Sistem pendukung keputusan teridi dari sistem cerdas (
Expert System). Sistem informasi eksekutif (Executive Information System) dan sistem pendukung keputusan (Eom, 2001). Secara khusus DSS didefinisikan sebagai teknologi computer yang digunakan untuk mendukung pengambilan keputusan dan penyelesaian masalah yang tidak terstruktur (Turban dkk, 2005).

\subsection{Simple Additive Weighting(SAW)}

Dalam Kusumadewi dkk. (2006), Fishburn menyatakan bahwa, konsep dasar metode simple additive weighting method (SAW) yang biasa disebut juga weighted sum model (WSM) adalah mencari penjumlahan terbobot dari rating kinerja pada setiap alternatif pada semua atribut. Metode SAW membutuhkan proses normalisasi matriks keputusan (x) ke suatu skala yang dapat diperbandingkan dengan semua rating alternatif yang ada.

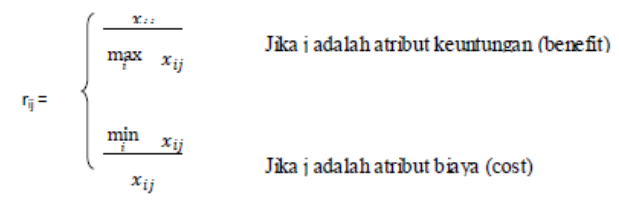

Dimana rij adalah rating kinerja ternormalisasi dari alternatif $\mathrm{Ai}$ pada atribut $\mathrm{Cj}$ dimana $\mathrm{i}=1,2, \ldots, \mathrm{m}$ dan $j=1,2, \ldots, n$. Nilai preferensi untuk setiap alternatif (Vi) diberikan sebagai :

$$
\mathrm{V} i=\sum_{j=1}^{n}\left(w_{j} r_{i j}\right)
$$

Nilai $\mathrm{V}_{\mathrm{i}}$ yang lebih besar mengindikasikan bahwa alternatif $A_{i}$ lebih terpilih.

Adapun langkah -langkah dalam metode SAW adalah sebagai berikut :

Langkah-langkah penyelesaian metode SAW

a. Membentuk matriks dari setiap nilai kriteria.

b. Menormalisasikan nilai input dari kriteria tersebut.

c. Memberi nilai pembobotan pada setiap kriteria

1. Keuntungan (Benefit).

2. Biaya (Cost).

d. Menentukan Perangkingan.

\section{Metodologi Penelitian}

\subsection{Metode SDLC}

Aplikasi Sistem pendukung keputusan ini menggunakan metode SDLC yang menggunakan pengembangan pada model waterfall. Karena model ini merupakan sekuensial linier yang 
istematis untuk pengembangan perangkat lunak yang dimulai pada tingkat perencanaan analisis sisem, desain sistem, implementasi atau pengkodean, dan pengujian. Berikut diagram model waterfall menurut referensi Sommerville

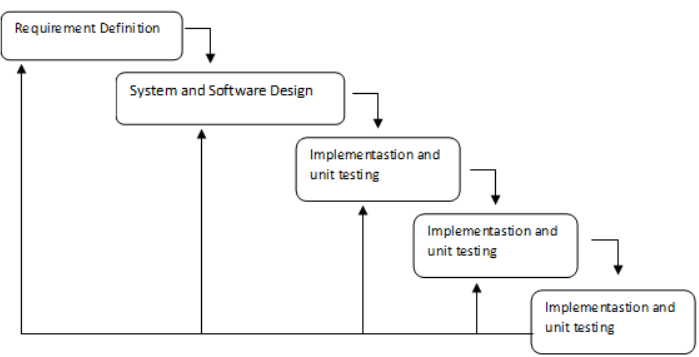

Gambar 1 Tahapan Penelitian

\section{Analisis dan Perancangan}

\subsection{Kebutuhan Input}

Sistem pendukung keputusan kelompok yang akan dibangun membutuhkan beberapa input, antara lain:

1. Data pengguna sistem seperti nama, username, password dan type pengguna (admin).

2. Data siswa seperti nisn, nama, username, password dan data probadi siswa.

3. Data kriteria yang akan digunakan sebagai parameter pemintan.

4. Data penilaian bobot masing-masing kriteria oleh admin.

5. Data subkriteria dan penilaian bobot subkriteria sesuai dengan data siswa.

\subsection{Kebutuhan output}

Output yang diharapkan adalah berupa informasi bagi para pengambil keputusan, yaitu:

1. Data siswa

2. Data kriteria dan subkriteria

3. Data hasil peminatan

4. Hasil perangkingan

5. Hasil sorting peminatan siswa

\subsection{Rancangan Model Peminatan}

Rancangan model digunakan untuk membangun sistem peminatan yang mampu memproses data-data peminatan sehingga didapatkan nilai akhir dan peringkat alternatif. Hasil penilaian setiap alternative akan disorting sesuai dengan kuota setiap minat yang tersedia di SMA Negeri 1 Tumpang.

Komponen sistem pendukung keputusan dapat dilihat pada gambar 4.1 yaitu subsistem manajemen basis data, sub sistem basis model dan sub sistem dialog latyar terminal (user interface).

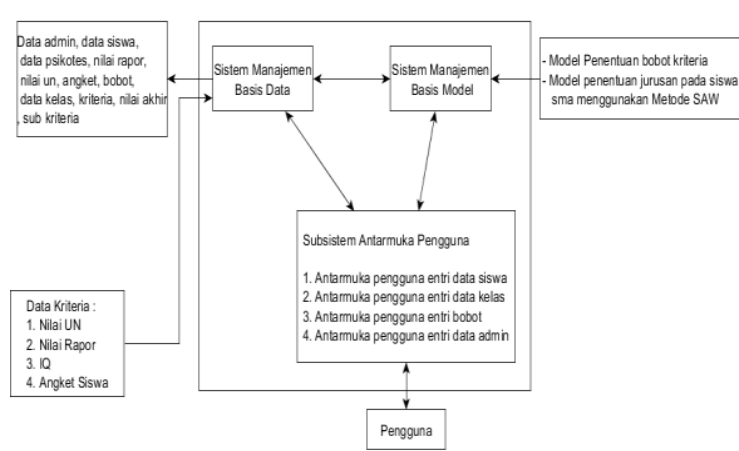

Gambar 2 Model SPK Peminatan

\subsection{Use Case Diagram}

Use Case diagram merupakan pemodelan untuk kelakuan (behavior) sistem yang akan dibuat. Use Case Diagram mendeskripsikan sebuah interaksi antara satu atau lebih actor dengan sistem yang akan dibuat (S.A, Rosa, 2013). Use Case Diagram digunakan untuk mengetahui fungsifungsi yang ada dalam sistem dan user mana saja yang berhak menggunakanya.

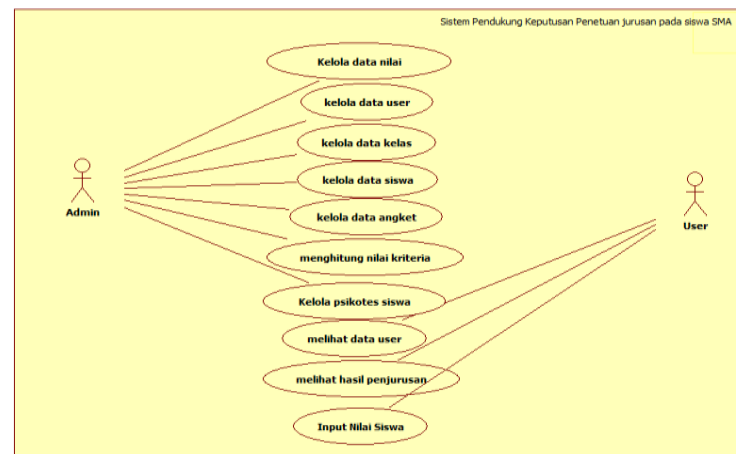

Gambar 3 Use Case Diagram

\section{Implementasi}

\subsection{Basis Data}

Pada dan basis data penjurusan sma terdapat 5 tabel, antara lain admin, penjurusan, sub_kriteria, kriteria dan limit.

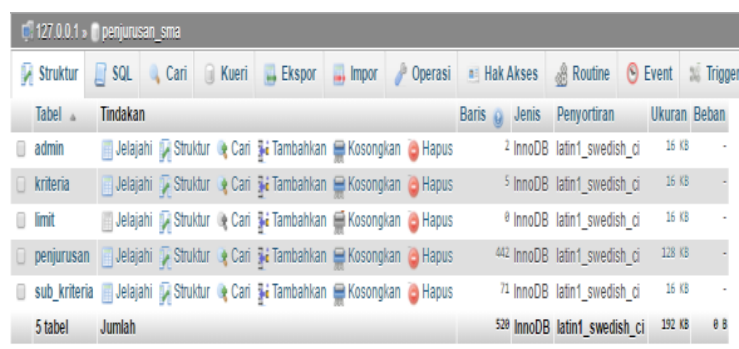

Gambar 4 Basis Data

\subsection{Implementasi Program}

\section{a. Halaman login}

Gambar 5.2 adalah halaman login. Untuk dapat masuk ke dalam aplikasi, user harus mengisi 
halaman login terlebih dahulu. User dalam aplikasi ini terdapat 2 user, yaitu siswa dan guru BK. Apabila user siswa melakukan login maka siswa akan diarahkan ke halaman User. Apabila Guru BK melakukan login maka akan diarahkan kehalaman Admin.

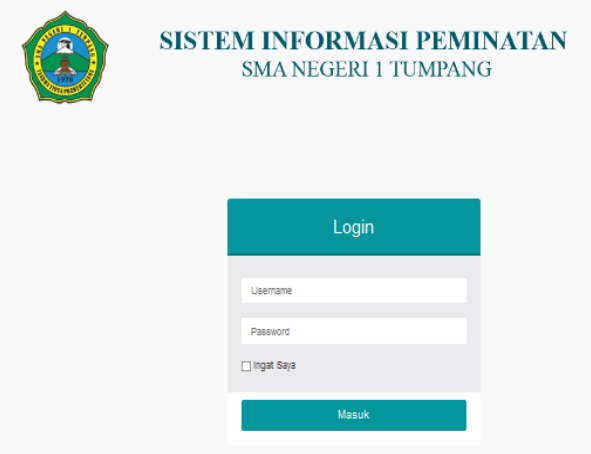

Gambar 5 Halaman Login

\section{b. Halaman normalisasi}

Normalisasi dilakukan dengan membagi nilai kriteria pada alternative dengan nilai maksimal kriteria.

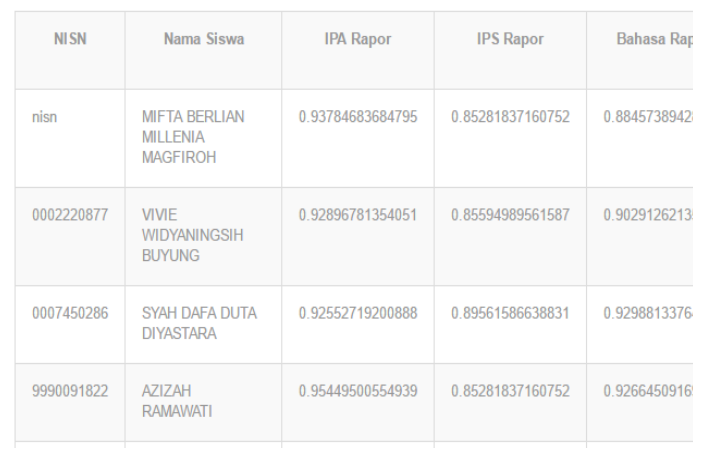

\section{Gambar 6 Normalisasi}

\section{c. Halaman perangkingan}

Perangkingan dilakukan dengan mengurutkan nilai tertinggi hingga terendah

\begin{tabular}{c|c|c}
\hline NISN & Nama Siswa & $\mathrm{H} a$ \\
\hline 9990090733 & NANDA SEPTY ANGGRAENI & 21. \\
\hline 9998638961 & SISKA ANDRIANI & 20.1 \\
\hline 0007439725 & ADNIN INTAN SYALSABILLA & 19.1 \\
\hline 9993304188 & AHMAD NUR SEPTIANTO & 19.1 \\
\hline nisn & MIFTA BERLIAN MILLENIA MAGFIROH & 19.1 \\
\hline
\end{tabular}

Gambar 7 Perangkingan

\section{Pengujian dan Pembahasan}

Pengujian dilakukan dengan pengujian metode secara manual dengan menggunakan excel

a. Data Nilai

Berikut merupakan data nilai yang telah dikalkulasikan sesuai dengan ketentuan dari SMA Negeri 1 Tumpang

\begin{tabular}{|l|c|c|c|c|c|c|c|c|c|c|c|}
\hline Alternatif & IPA_R & IPS_R & BHS_R & IPA_U & IPS_U & BHS_U & M1 & M2 & M3 & Q & WA \\
\hline INDI & 53,8 & 55,0 & 52,9 & 138,25 & 70 & 128,8 & 5,0 & 4 & 3 & 87 & 1 \\
\hline ROBBI & 54,9 & 54,4 & 50,1 & 136,5 & 66,5 & 123,2 & 5,0 & 4 & 3 & 93 & 5 \\
\hline OKTAVIA & 51,9 & 50,3 & 51,1 & 134,75 & 66,5 & 126 & 5,0 & 4 & 3 & 89 & 5 \\
\hline ALDA & 57,0 & 55,9 & 55,6 & 129,5 & 64,75 & 128,8 & 5,0 & 4 & 3 & 92 & 5 \\
\hline
\end{tabular}

Gambar 8 data nilai

b. Penentuan Range Nilai

Normalisasi dilakukan dengan menggunakan rumus sebagai berikut:

1. Mencari nilai maksimal (max) dan minmal (min)

2. Mententukan rentangan $(\mathrm{R})$

$$
\mathrm{R}=\max -\min
$$

3. Menentukan Banyaknya kelas (BK)

$$
\mathrm{BK}=1+3,3 * \log \mathrm{n}
$$

4. Menentukan panjang kelas

$$
\mathrm{I}=\mathrm{R} / \mathrm{BK}
$$

\begin{tabular}{|c|c|c|c|c|c|c|c|}
\hline & IPA_R & IPS_R $^{\prime}$ & BHS_R & IPS_U & IPS_U & BHS_U & WA \\
\hline Max & 57,0 & 55,9 & 55,6 & 138,3 & 70,0 & 128,8 & 5,0 \\
\hline Min & 51,9 & 50,3 & 50,1 & 129,5 & 64,8 & 123,2 & 1,0 \\
\hline R & 5,1 & 5,6 & 5,5 & 8,8 & 5,3 & 5,6 & 4,0 \\
\hline BK & 3,3 & 3,3 & 3,3 & 3,3 & 3,3 & 3,3 & 3,3 \\
\hline I & 1,5 & 1,6 & 1,6 & 2,64 & 1,5 & 1,6 & 1,2 \\
\hline
\end{tabular}

Gambar 9 Data Nilai

Setelah melakukan rumus, selanjutnya mencari interval setiap nilai yaitu range bawah dan range bawah, dan untuk mendapatkan range bawah dan range lihat contoh berikut:

Range bawah $=\min -0,5$

Range atas $=$ range bawah $+\mathrm{I}+0,5$

Berikut merupakan hasil range untuk nilai ipa rapor

\begin{tabular}{|c|c|c|c|}
\hline & range bawah & range atas & bobot \\
\hline $\begin{array}{c}\text { Interval IPA } \\
\text { Rapor }\end{array}$ & 51,400 & 53,442 & 1 \\
\hline & 53,452 & 55,495 & 2 \\
\hline & 55,505 & 57,547 & 3 \\
\hline
\end{tabular}

Gambar 10 Range Nilai ipa Rapor 
c. Convert

\begin{tabular}{|c|c|c|c|c|c|c|c|c|c|c|}
\hline Aiternatif & IPA_R & IPS_R & BHS_R & IPA_U & IPS_U & BHS_U & M1 & M2 & M3 & |Q \\
\hline INDI & 2 & 3 & 2,0 & 3 & 3 & 3 & 5 & 4 & 3,0 & 9 \\
\hline ROBBI & 2,0 & 3,0 & 1,0 & 3 & 2 & 1 & 5 & 4 & 3,0 & 10 \\
\hline OKTAVIA & 1,0 & 1,0 & 1,0 & 2 & 2 & 2 & 5 & 4 & 3,0 & 9 \\
\hline ALDA & 3,0 & 3,0 & 3,0 & 1 & 1 & 3 & 5 & 4 & 3,0 & 10 \\
\hline HANNA & 2,0 & 3,0 & 3,0 & 1 & 2 & 1 & 5 & 4 & 3,0 & 10,0 \\
\hline
\end{tabular}

Gambar 11 convert

d) Normalisasi

Normalisasi dilakukan dengan membagi nilai kriteria dengan nilai maksimal dari seluruh alternative

\begin{tabular}{|l|c|c|c|c|c|c|c|c|c|c|c|}
\hline Alternatif & IPA_R & IPS_R & BHS_R & IPA_U & IPS_U & BHS_U & M1 & M2 & M3 & IQ \\
\hline INDI & 0,67 & 1,00 & 0,67 & 1,00 & 1,00 & 1,00 & 1,00 & 1,00 & 1,00 & 0,90 \\
\hline ROBBI & 0,67 & 1,00 & 0,33 & 1,00 & 0,67 & 0,33 & 1,00 & 1,00 & 1,00 & 1,00 \\
\hline OKTAVIA & 0,33 & 0,33 & 0,33 & 0,67 & 0,67 & 0,67 & 1,00 & 1,00 & 1,00 & 0,90 \\
\hline ALDA & 1,00 & 1,00 & 1,00 & 0,33 & 0,33 & 1,00 & 1,00 & 1,00 & 1,00 & 1,00 \\
\hline HANNA & 0,67 & 1,00 & 1,00 & 0,33 & 0,67 & 0,33 & 1,00 & 1,00 & 1,00 & 1,00 \\
\hline
\end{tabular}

Gambar 12 Normalisasi

e) Nilai Preverensi

Nilai preferensi didapatkan dapatkan dari nilai dikalikan dengan bobot kriteria

$$
\begin{aligned}
& \mathrm{V} 1=(3 * 0,67)+(3 * 0,1)+(3 * 0,67)+(3 * 1)+(3 * 1)+ \\
&(3 * 1)+\left(1,5^{*} 1\right)+(1,5 * 1)+(1,5 * 1)+(2 * 0,9)+ \\
&(0,5 * 0,33)=22,46666667 \\
& \mathrm{~V} 2=(3 * 0,67)+(3 * 1)+(3 * 0,33)+(3 * 1)+(3 * 0,67)+ \\
&(3 * 0,3)+(1,5 * 1)+(1,5 * 1)+(1,5 * 1)+(2 * 1)+ \\
&(0,5 * 1)=19 \\
& \mathrm{~V} 3=(3 * 0,33)+(3 * 0,33)+(3 * 0,33)+(3 * 0,67)+ \\
&(3 * 0,67)+(3 * 0,67)+(1,5 * 1)+(1,5 * 1)+ \\
&(1,5 * 1)+(2 * 0,9)+(0,5 * 1)=15,8 \\
& \mathrm{~V} 4=(3 * 1)+(3 * 1)+(3 * 1)+(3 * 33)+(3 * 0,33)+(3 * 1)+ \\
&(1,5 * 1)+(1,5 * 1)+(1,5 * 1)+(2 * 1)+(0,5 * 1)= \\
& 21 \\
& \mathrm{~V} 5=(3 * 0,67)+(3 * 1)+(3 * 0,33)+(3 * 0,33)+(3 * 0,67) \\
&+(3 * 0,33)+(1,5 * 1)+(1,5 * 1)+(1,5 * 1)+(2 * 1) \\
&+(0,5 * 0,33)=18,66667
\end{aligned}
$$

Tabel 1 Nilai Preferensi

\begin{tabular}{|l|c|}
\hline Alternatif & Nilai \\
\hline INDI IZZA AFDANIA & 22,46666667 \\
\hline $\begin{array}{l}\text { ROBBI YAHYA GIRI } \\
\text { KAUTSAR }\end{array}$ & 19 \\
\hline OKTAVIA FIRNANDA & 15,8 \\
\hline $\begin{array}{l}\text { ALDA DINDA } \\
\text { OKTAVIANA }\end{array}$ & 21 \\
\hline $\begin{array}{l}\text { HANNA FAUZIAH } \\
\text { HABIBAH }\end{array}$ & 18,666667 \\
\hline
\end{tabular}

f) Perangkingan

Perangkingan merupakan lagkah terakhir dalam metode SAW

Tabel 2 Perangkingan

\begin{tabular}{|l|c|}
\hline Nama Siswa & Nilai \\
\hline INDI IZZA AFDANIA & 22,46666667 \\
\hline ALDA DINDA OKTAVIANA & 21 \\
\hline HANNA FAUZIAH HABIBAH & 18,66666667 \\
\hline $\begin{array}{l}\text { ROBBI YAHYA GIRI } \\
\text { KAUTSAR }\end{array}$ & 19 \\
\hline OKTAVIA FIRNANDA & 15,8 \\
\hline
\end{tabular}

g) Pengujian Hasil

Hasil pengujian didapatkan dengan menggunakan pengujian manual hasil penentuan seleksi penjurusan dengan data sample siswa 5 orang menggunakan metode SAW dengan hasil pengujian sistem, hasil pengujian dapat lihat sebagai berikut,

Tabel 13 Hasil pengujian menggunakan data manual

\begin{tabular}{|l|c|l|l|}
\hline Nama Siswa & Hasil Pengujian Manual & Hasil Pengujian SPK & \\
\hline Indi izza afdania & 22,4666667 & 22.4667 & \\
\hline Alda dinda oktaviana & 21 & 21 & \\
\hline Robbi yahya giri kautsar & 19 & 19 & \\
\hline Hanna fauziah habibah & 18,6666667 & 18.6667 & 15.8 \\
\hline Oltavia fimanda & 15,8 & 15.8 & \\
\hline
\end{tabular}

Dalam pengujian hasil penentuan penjurusan, keputusan dikembalikan kepada pihak pengambil keputusan yaitu Guru Bimbingan Konseling SMA Negeri 1 Tumpang yang berwenang. 


\section{Kesimpulan dan Saran}

\subsection{Kesimpulan}

Berdasarkan Pembahasan pada bab 1 hingga bab 6 dapat disimpulkan bahwa :

a) Sistem ini telah berhasil menerapkan metode SAW untuk pengambilan keputusan penentuan penjurusan di SMA Negeri 1 Tumpang.

b) Hasil pengujian menunjukan bahwa perancangan menghasilkan sistem yang dapat membantu pengambilan keputusan penentuan penjurusan pada siswa sma.

Hasil pengujian menunjukan bahwa performansi sistem ini sudah baik dan menghasilkan hasil yang cukup akurat. Berdasarkan hasil pengujian tersebut, Sistem Pendukung Keputusan memiliki keakurasian $85,39 \%$ pada tahun 2015 dan $77,04 \%$ pada tahun 2014.

\subsection{Saran}

Berdasarkan penelitian yang dilakukan, berikut saran untuk pengembangan aplikasi Sistem Pendukung Keputusan ini lebih lanjut, yaitu aplikasi dapat ditambahkan fitur untuk menambah kriteria dan sub kriteria secara dinamis agar aplikasi dapat dipakai dalam jangka panjang dan dapat disesuaikan dengan ketentuan penjurusan yang berlaku.

\section{Daftar Pustaka:}

Dewi, Ayu, Prima. 2015., Pengembangan Sistem Pendukung Keputusan untuk Menentukan Penerima Bantuan Raskin Dengan Menggunakan Metode TOPSIS(Studi Kasus : Kota Malang). Skripsi Tidak Diterbitkan.

Hartini.D, C., et all., 2013. "Sistem Pendukung Keputusan Pemilihan Hotel Di Kota Palembang Dengan Metode Simple Additive Weighting(SAW)". Journal Sistem Informasi (JSI), Vol. 5, NO.1, April 2013, ISSN Print : 2085-1588.

Kendal Kennet. E dan Kendall Julie.E, 2003. Analisis dan Perancangan Sistem,. edisi ke-5 jilid 2. Jakarta. PT INDEKS, Kelompok GRAMEDIA.

Kusrini. 2007. Konsep dan Aplikasi Sistem Pendukung Keputusan. Yogyakarta : ANDI.

Kusumadewi,Sri dan Purnomo,Hari. 2010. Aplikasi Logika Fuzzy untuk Pendukung Keputusan. Yogyakarta: Graha Ilmu.

Muntle.H, G., 2013. "Sistem Pendukung Keputusan Penentuan Prioritas Usulan Sertifikasi Guru Dengan Metode Simple Additive Weighting". ISSN: 2301-9425.

Riduwan. 2013. Dasar - Dasar Statistika. Bandung : Alfabeta.

SMA Negeri 1 Tumpang.2015. Standar Operasional Prosedur (Sop) Peminatan
Dan Lintas Minat Peserta Didik. Buku SOP Tidak Diterbitkan.

Silalahi.M, S., 2013. "Sistem Pendukung Keputusan Kenaikan Jabatan Degan Metode Simple Additive Weighting(SAW)(Studi Kasus : GAPEKSINDO MEDAN)". ISSN : 2301-9425.

Wibowo, Herry., et all., 2009. "Sistem Pendukung Keputusan untuk Menentuka Penerima Beasiswa BANK BRI Menggunakan FMADM(Studi Kasus : Mahasiswa Fakultas Teknologi Indutri Universitas Islam Indonesia)". ISSN: 1907-5022. 